\title{
Spring fen Scheuchzerio-Caricetea nigrae in the Polish Western Carpathians - vegetation diversity in relation to soil and feeding waters
}

\author{
Anna Koczur ${ }^{1 *}$, Paweł Nicia ${ }^{2}$ \\ ${ }^{1}$ Institute of Nature Conservation, Polish Academy of Sciences, Mickiewicza 33, 31-120 Cracow, Poland \\ ${ }^{2}$ Department of Soil Science and Soil Protection, Agricultural University of Cracow, Mickiewicza 21, 31-120 Cracow, Poland
}

\section{Abstract}

The species composition of vegetation associated with the Carpathian fens primarily depends on the type of water present and the hydrological feeding of the soils that occur there. These, in turn, shape the fertility of the fens. Those with typically formed Carici-Agrostietum caninae and Valeriano-Caricetum flavae fundamentally differ in the properties of their soils and feeding waters. These include differences in mineral content, $\mathrm{pH}, \mathrm{CaCO}_{3}$ levels, degree of peat decomposition, electrical conductivity and oxygenation of the waters that feed the fens. Carici-Agrostietum caninae is a homogenous plant association adapted to extreme habitat conditions. It is characterized by a very narrow range of essential soil and feeding water parameters. Valeriano-Caricetum flavae is a highly diverse association. Considerable diversity both in terms of plant species and vegetation structure reflects very wide ranges in the properties of soil and feeding water. Vegetation patches of transitory character were also identified. These contained plant species characteristic of both associations. The character of the vegetation depends mainly on fen soil $\mathrm{pH}$ and the degree of mineralization of the feeding waters. It is only these parameters that allow intermediate patches to be clearly distinguished. The degree of peat decomposition, mineral content and water oxygenation all differ for Carici-Agrostietum caninae and ValerianoCaricetum flavae, whereas the values for intermediate patches display a range of parameters typical of both investigated associations. Consequently, vegetation present in these patches reflects to a greater or lesser extent one of the two analyzed plant associations.

Keywords: Carici-Agrostietum caninae, Valeriano-Caricetum flavae, fens, soil and water properties, Western Carpathians, Poland

\section{Introduction}

The accumulation of organic matter derived from plants growing in fens results in the formation of peat in fen soils subjected to very wet conditions. Depending on the type of hydrological feeding present, fen waters vary greatly in terms of their mineral and ion composition $[1,2]$. As water flows through organic matter deposited during the formation of peat, it becomes enriched with minerals and thus, contributes to soil fertility. Fens of this kind can be divided into two groups, based on the type of hydrological feeding present. Firstly, soligenic fens are rich fens that form on a lime substratum, or moderately rich fens that develop on flysch bedrock of subMagura and mid-Magura layers, or on glacial deposits. The second group consists of poor fens that are fed by precipitation

*Corresponding author. Email: koczur@iop.krakow.pl

Handling Editor: Zygmunt Dajdok

This is an Open Access digital version of the article distributed under the terms of the Creative Commons Attribution 3.0 License (creativecommons.org/licenses/by/3.0/), which permits redistribution, commercial and non-commercial, provided that the article is properly cited. waters, and these develop on a matrix lacking in carbonate. In the Polish Western Carpathians these are usually colonized by vegetation characteristic of Valeriano-Caricetum flavae and Agrostietum caninae associations [3]. Rich soligenic fen soils are characterized by their high degree of mineralization and the proportion of calcium cations involved in general mineralization. The concentration of calcium cations and the degree of mineralization of poor fen waters that display an ombrogenic type of feeding is many times lower [2,4]. On the basis of field investigations, a third group of fens was identified. Physical and chemical properties of their soils and waters were described as intermediate. These fens are called mesotrophic fens by Kornaś and Medwecka-Kornaś [5].

The aim of this work is to demonstrate that differences in the floristic composition of these plant communities reflect the physicochemical properties of the soil on which they grow.

\section{Investigated area}

Detailed analyses conducted during the period 2001-2006 investigated 20 selected fens distributed throughout the area of the Western Carpathians (the Tatra Mountains, the Subtatra Trough, the Spisko-Gubałowskie Foothills, the Pieniny Mountains, the Orawa-Nowy Targ Basin, the Gorce Mountains, Działy Orawskie Mountains, and the Babia Góra Range; Fig. 1). These fens were located at altitudes of between 530 and $925 \mathrm{~m}$ a.s.l., which, based on vegetation type, corresponds to a lower 


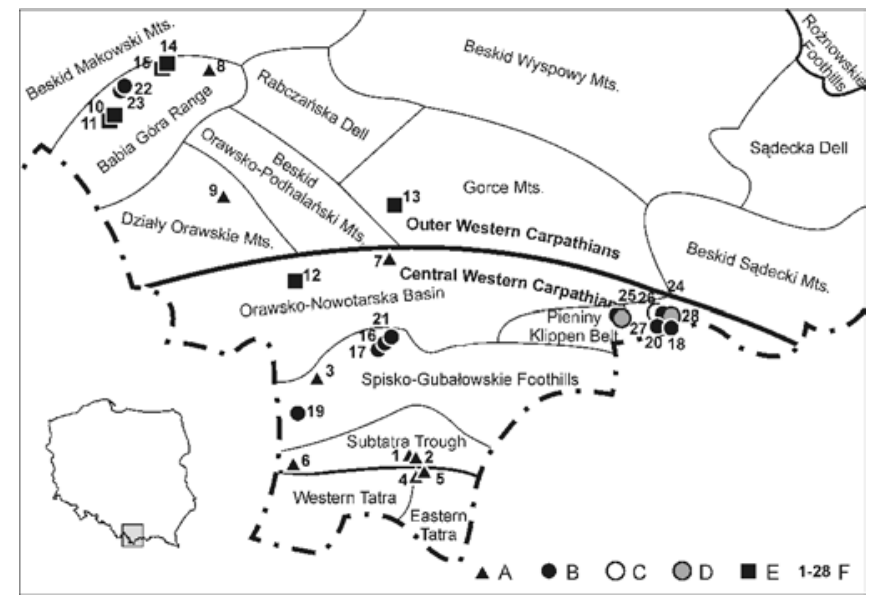

Fig. 1 Location of the investigated spring fens against the background of physiographic division of the Polish Carpathians after Kondracki [26]. A - Carici-Agrostietum caninae. B - Valeriano-Caricetum flavae. C - Caricetum davallianae. D - Eleocharitetum pauciflorae. E - intermediate patches. F - patch numbers: 1 - Murzasichle 2; 2 Murzasichle 1; 3 - Podczerwone; 4 - Palenica Pańszczykowa, central part; 5 - Palenica Pańszczykowa, lower part; 6 - Polana Szczurówka; 7 - Pod lasem Grel; 8 - Zawoja Mosorne; 9 - Zubrzyca Górna; 10 Norczak 1; 11 - Norczak 2; 12 - Baligówka; 13 - Pod Klikuszową; 14 - Markowe Rówienki 1; 15 - Markowe Rówienki 2; 16 - Maruszyna, upper part; 17 - Maruszyna, central part; 18 - Za Stronią below water seepage; 19 - Dzianisz; 20 - Młaka Franka; 21 - Maruszyna, lower part; 22 - Barańcowa 1; 23 - Barańcowa 2; 24 - Za Stronią above water seepage; 25 - Majerz; 26 - Roplichta; 27 - Majerz, along watercourse; 28 - Za Stronią, central part.

mountain forest zone [6]. Fens varied in size from several dozen to several hundreds of square meters. In most cases, fens formed enclaves within meadows, and were used in a similar manner. The vegetation was mowing at least once every 3-4 years. Some adjoined pastures were occasionally grazed.

\section{Material and methods}

Between one and three soil pits were made on each of the fens selected for analysis, in order to determine the basic morphological, chemical and physical properties of their soils. Piezometers were installed at the site of the soil pits, and water was sampled every month throughout the period March-December. Rich fens were investigated during 2000-2001, poor fens during 2003-2004 and mesotrophic fens during 2005-2006. The following criteria were measured for soil samples taken from investigated fens: $\mathrm{pH}$ was measured using the potentiometric method in water and $1 \mathrm{M} \mathrm{KCl}$, mineral content in organic horizons as a percentage weight loss following heating at $550^{\circ} \mathrm{C}$ [7], peat decomposition was assessed by means of the ten-degree von Post scale [8] and calcium carbonate content was calculated using the Scheibler method. The degree of oxygenation of water samples was measured by means of a CO-315 oxygen meter, together with electrical conductivity [9].

In order to identify and characterize plant associations, 27 phytosociological relevès were made in accordance with the method of Braun-Blanquet. The analyses were conducted during 2003-2006, but one phytosociological relevè made in 2000, was also included. Depending on fen size and the diversity of its vegetation, one, two, and in some cases, even three phytosociological relevès were investigated for each fen. The investigated patches were selected so that the soil pit of each was at the center. In the case of larger, but homogenous patches, two or three closely situated soil pits occurred within a single phytosociological relevè.

Identification and distinction between plant communities followed Matuszkiewicz [3], Ratyńska et al. [10], Chytrý [11] and others (e.g. [5,12-17]). The syntaxonomic division of communities followed Ratyńska et al. [10]. Names of vascular plants and bryophytes followed Mirek et al. [18] and Ochyra et al. [19], respectively.

Phytosociological relevès were grouped using classic methodology and the sets obtained were compared with the results of hierarchical numerical classification [20-22]. Hierarchical numerical classification was conducted twice: 1 - based on the species present ( $0-1$ scale), where dissimilarities between the relevès were computed using the Jaccard formula; and 2 - on the basis of coverage by species, using the 1-6 cover scale of Braun-Blanquet, where “+” $=0.5$. In this case Manhattan was used. For trees and shrubs, the presence and degree of cover by individual species was given separately for each plant layer. Unweighted pair group method with arithmetic mean (UPGMA) was used for grouping. Differences in properties of soils and waters were determined by means of the Kruskal-Wallis test.

\section{Results}

\section{Plant communities of the analyzed fens}

Vegetation overgrowing fens in the Polish Western Carpathians comprises the Scheuchzerio-Caricetea fuscae class and consists of low sedge waterlogged meadows abundant in bryophytes and immersive low and transitory peatbogs [3].

The investigated fens can be divided into two alliances: Caricion fuscae and Caricion davallianae, each belonging to the Caricetalia fuscae order [10]. Patches of intermediate character were often observed among rich spring fens (Caricion davallianae alliance) [12]. When water relations were disturbed (e.g. by an irrigation system) these associations became transformed into meadow communities, mainly wet meadows of the Molinietalia order.

The investigated patches were divided into three groups (Tab. 1), based on species composition:

(i) Poor fens (Caricion fuscae alliance), represented by Carici-Agrostietum caninae association.

The mean number of species in the investigated patches was 25.6 (range $=15-33$ ). The characteristic plants were Agrostis canina, Carex canescens and C. echinata. Species typical of the Caricion fuscae alliance - Viola palustris, Polytrichum commune, Juncus filiformis and Ranunculus flammula were also very numerous. Of those species characteristic of the Caricetalia fuscae order and the Scheuchzerio-Caricetea fuscae class, the most frequently encountered were Carex nigra and Eriophorum angustifolium. Plants typical of other biotopes usually consisted of a small number of species. The moss layer was usually well formed (50-100\% cover in the investigated patches) Polytrichum commune and Sphagnum angustifolium were the most numerous species. Carici-Agrostietum, a homogenous plant association (Fig. 2), was clearly distinguishable from the surrounding plant communities. 
(ii) Rich fens (Caricion davallianae alliance), were represented mainly by the Valeriano-Caricetum flavae association. One phytosociological relevè should be classified as Caricetum davallianae, two others as Eleocharitetum pauciflorae [11].

The vegetation of these fens was abundant in species, (mean number of species $=37$; range $=19-48$ ). Valeriano-Caricetum flavae characteristic species, which occur here quite permanently, are Valeriana simplicifolia, Eriophorum latifolium, Carex flava and the much rarer C. lepidocarpa. Carex davalliana dominated the patch classified as Caricetum davallianae. However, it was present in much smaller numbers in the remaining patches. Eleocharis quinqueflora and Triglochin palustre grew exclusively in Eleocharitetum pauciflorae patches. Species characteristic of the Caricion davallianae alliance, such as Epipactis palustris, Dactylorhiza majalis and Carex flacca were numerous. Of those species characteristic of the Caricetalia fuscae order and Scheuchzerio-Caricetea fuscae class, the most frequently encountered were Carex panicea and C. nigra. Plants primarily characteristic of meadow associations (Briza media, Caliergonella cuspidata, Caltha laeta, Cirsium palustre, C. rivulare, Climacium dendroides, Crepis paludosa, Cruciata gabra, Equisetum palustre, Galium uliginosum, Linum catharticum, Myosotis palustris, Plagiomnium elatum, Potentilla erecta, $\mathrm{Ra}$ nunculus acris) were numerous represented and even dominated in many relevès. Some rushes species (Equisetum fluviatile, Carex paniculata) were also frequent in these associations. The moss layer was very well developed, and displayed 30-100\% cover, depending on the degree of hydration. Species of wet habitats were the most frequent whereas species characteristic of the Scheuchzerio-Caricetea fuscae class appeared to abort in $50 \%$ of the investigated patches. A characteristic phenomenon indicating considerable water movement was the shared presence of both spring species (Montio-Cardaminetea class) and species characteristic of Caricion lasiocarpae (i.e., Calliergon giganteum, Tomentypnum nitens). These are indicators of local acid conditions and occurred only occasionally.

Dominant among rich fens, Valeriano-Caricetum flavae is a heterogeneous, strongly diversified association (Fig. 2), forming a number of variants. Different species dominated in individual patches, and plants recognized as characteristic for the described association, alliance, order, or some plants typical of wet meadows or rushes plants were often the dominant taxa.

(iii) Patches of transitional character with species characteristic of both identified groups.

Patches classified as intermediate were among those which were most abundant in species, the mean number of species being 38.8, with individual phytosociological relevès displaying a range of 26-51. They are identified by the presence of species characteristic of the Carici-Agrostietum canine association and the Caricion fuscae alliance (Agrostis canina, Carex echinata, Viola palustris), and those typical of the Valeriano-Caricetum flavae association, and the Caricion davallianae alliance (Carex flava, Dactylorhiza majalis, Epipactis palustris, Eriophorum latifolium, Valeriana simplicifolia). As in the case of Valeriano-Caricetum flavae, species typical of other communities, primarily meadow and rushes communities, were present in some numbers. The moss layer showed great diversity and displayed a cover range of 10-90\%. Species characteristic of both moist and wet habitats were present here, including both species typical of rich fens and springs. A characteristic feature was the small overlap of species characteristic of the Caricion lasiocarpae alliance (Calliergon giganteum, Sphagnum teres, S. warnstorfii).
Tab. 1 Plant communities of spring fens (Scheuchzerio-Caricetea nigrae).

\begin{tabular}{|c|c|c|c|c|}
\hline \multirow[b]{2}{*}{ Number of relevés } & I & II & III & \multirow[b]{2}{*}{$1-28$} \\
\hline & $1-9$ & $10-15$ & $16-28$ & \\
\hline \multicolumn{5}{|l|}{ Ch. Caricion fuscae } \\
\hline Carex echinata & $\mathrm{V}^{(+-3)}$ & $\mathrm{V}^{(+)}$ & $I^{(+-1)}$ & III \\
\hline Agrostis canina & $\mathrm{V}^{(+-3)}$ & $I^{(1)}$ & $I^{(+)}$ & II \\
\hline Viola palustris & $\mathrm{IV}^{(+-3)}$ & $\mathrm{I}^{(1)}$ & $I^{(+)}$ & II \\
\hline Carex canescens & $\mathrm{IV}^{(+-3)}$ & - & - & II \\
\hline Polytrichum commune & III $^{(2-5)}$ & - & - & I \\
\hline Juncus filiformis & III $^{(1-2)}$ & - & - & I \\
\hline Ranunculus flammula & IIII $^{(+-2)}$ & - & - & I \\
\hline
\end{tabular}

Ch. Caricion davallianae

Valeriana simplicifolia

Dactylorhiza majalis

Epipactis palustris

Eriophorum latifolium

Carex flava

Carex flacca

Carex lepidocarpa

Pinguicula vulgaris

Bryum pseudotriquetrum

Parnassia palustris

Carex davalliana

Eleocharis quinqueflora

Triglochin palustre

Dactylorhiza incarnata

Polygala amarella

$\begin{array}{cccc}\mathrm{I}^{(+)} & \mathrm{IV}^{(+-1)} & \mathrm{V}^{(+-4)} & \mathrm{IV} \\ \mathrm{I}^{(+)} & \mathrm{IV}^{(+-1)} & \mathrm{IV}^{(+-2)} & \mathrm{III} \\ - & \mathrm{I}^{(1)} & \mathrm{V}^{(1-3)} & \mathrm{III} \\ - & \mathrm{III}^{(+-1)} & \mathrm{IV}^{(+-3)} & \mathrm{III} \\ - & \mathrm{III}^{(+-1)} & \mathrm{III}^{(+-2)} & \mathrm{II} \\ - & - & \mathrm{IV}^{(+-2)} & \mathrm{II} \\ \mathrm{II}^{(+)} & \mathrm{I}^{(+)} & \mathrm{I}^{(1)} & \mathrm{I} \\ - & \mathrm{I}^{(+)} & \mathrm{II}^{(+-1)} & \mathrm{I} \\ - & \mathrm{I}^{(+)} & \mathrm{I}^{(2)} & \mathrm{I} \\ - & \mathrm{I}^{(+)} & - & \mathrm{I} \\ - & - & \mathrm{II}^{(+-4)} & \mathrm{I} \\ - & - & \mathrm{II}^{(1-2)} & \mathrm{I} \\ - & - & \mathrm{II}^{(+)} & \mathrm{I} \\ - & - & \mathrm{I}^{(1)} & \mathrm{I} \\ - & - & \mathrm{I}^{(+)} & \mathrm{I}\end{array}$

\section{Ch. Caricetalia fuscae}

Carex nigra

Carex panicea

Epilobium palustre

Juncus articulatus

Pedicularis palustris

Drepanocladus aduncus

Veronica scutellata

$\begin{array}{cccc}\mathrm{V}^{(1-3)} & \mathrm{V}^{(2-3)} & \text { III }^{(+-1)} & \text { IV } \\ \mathrm{II}^{(+-2)} & \mathrm{V}^{(+-2)} & \mathrm{V}^{(+-2)} & \text { IV } \\ \mathrm{II}^{(1-2)} & \text { III }^{(+)} & \mathrm{I}^{(1)} & \text { II } \\ \mathrm{I}^{(+)} & \text {III }^{(+-1)} & \text { II }^{(+-2)} & \text { II } \\ - & \mathrm{I}^{(+)} & \mathrm{I}^{(1)} & \text { I } \\ - & - & \mathrm{I}^{(3)} & \text { I } \\ \mathrm{I}^{(+)} & - & - & \text {I }\end{array}$

Ch. Caricion lasiocarpae

Calliergon giganteum

Sphagnum teres

Sphagnum warnstorfii

Tomentypnum nitens

Ch. Scheuchzerietalia palustris

Sphagnum angustifolium

Straminergon stramineum

Sphagnum fallax

$\begin{array}{cc}\mathrm{III}^{(3-5)} & \mathrm{I}^{(+)} \\ \mathrm{II}^{(3)} & \mathrm{I}^{(1)} \\ \mathrm{II}^{(1-2)} & -\end{array}$

I

I

Ch. Scheuchzerio-Caricetea nigrae

Hamatocaulis vernicosus

Eriophorum angustifolium

$\mathrm{II}^{(1)} \quad \mathrm{II}^{(+-4)} \quad \mathrm{II}^{(+-3)} \quad$ II

Limprichtia revolvens

$\begin{array}{cccc}\mathrm{III}^{(+-3)} & \mathrm{I}^{(1)} & - & \mathrm{I} \\ - & - & \text { II }^{(2-3)} & \text { I }\end{array}$

Ch. Montio-Cardaminetea

Cardamine amara

Palustriella decipiens

$\mathrm{II}^{(+)} \quad \mathrm{I}^{(+)} \quad \mathrm{I}$

III ${ }^{(+-4)} \quad I^{(2-3)} \quad$ I

\section{Ch. Phragmitetea}

Galium palustre

IV
IV
II
II
I
I
I


Tab. 1 (continued)

\begin{tabular}{|c|c|c|c|c|}
\hline & I & II & III & \\
\hline Number of relevés & $1-9$ & $10-15$ & $16-28$ & $1-28$ \\
\hline Equisetum fluviatile & $\mathrm{II}^{(+-2)}$ & III $^{(+-2)}$ & III $^{(+-5)}$ & II \\
\hline Poa palustris & - & $\mathrm{II}^{(+)}$ & $\mathrm{II}^{(+-1)}$ & II \\
\hline Carex paniculata & - & - & III (1) & II \\
\hline Carex rostrata & - & $I^{(3)}$ & $\mathrm{II}^{(+-2)}$ & I \\
\hline
\end{tabular}

\section{Ch. Molinietalia}

Equisetum palustre

Cirsium rivulare

Caltha laeta

Myosotis palustris

Cirsium palustre

Crepis paludosa

Lychnis flos-cuculi

Juncus effusus

Galium uliginosum

Deschampsia caespitosa

Juncus conglomeratus

Scirpus sylvaticus

Climacium dendroides

Lysimachia vulgaris

Angelica sylvestris

Caltha palustris

Carex cespitosa

\section{Ch. Arrhenatheretalia}

Lotus corniculatus

Galium mollugo

Ch. Molinio-Arrhenatheretea

Ranunculus acris

Rumex acetosa

Lathyrus pratensis

Prunella vulgaris

Vicia cracca

Holcus lanatus

Juncus inflexus

Trifolium pratense

Lysimachia nummularia

Mentha longifolia

Poa pratensis

Festuca pratensis

Rhinanthus minor

\section{Ch. Nardo-Callunetea}

Potentilla erecta

Nardus stricta

Luzula campestris

Others

Briza media

Calliergonella cuspidata

Cruciata glabra

Anthoxanthum odoratum

Picea abies

Rhytidiadelphus squarrosus

Trifolium medium

Linum catharticum

Geum rivale
Relationship between spring fen vegetation, the soil reaction, and electric conductivity of feeding waters

Analysis of the acquired data revealed that both described groups of plant associations, identified on the basis of differences in their floristic composition, occurred in biotopes differing in $\mathrm{pH}$. They also differed in the degree of mineralization of feeding water, as shown by electric conductivity measurements (Fig. 3). These differences were statistically significant (Tab. 2).

Soils bearing patches of Carici-Agrostietum caninae were characterized by low $\mathrm{pH}$ values (Fig. 3 ) in $\mathrm{KCl}$ (mean = 3.73; range $=3.29-4.73$ ), whereas their feeding waters displayed low mineralization, as indicated by their electric conductivity

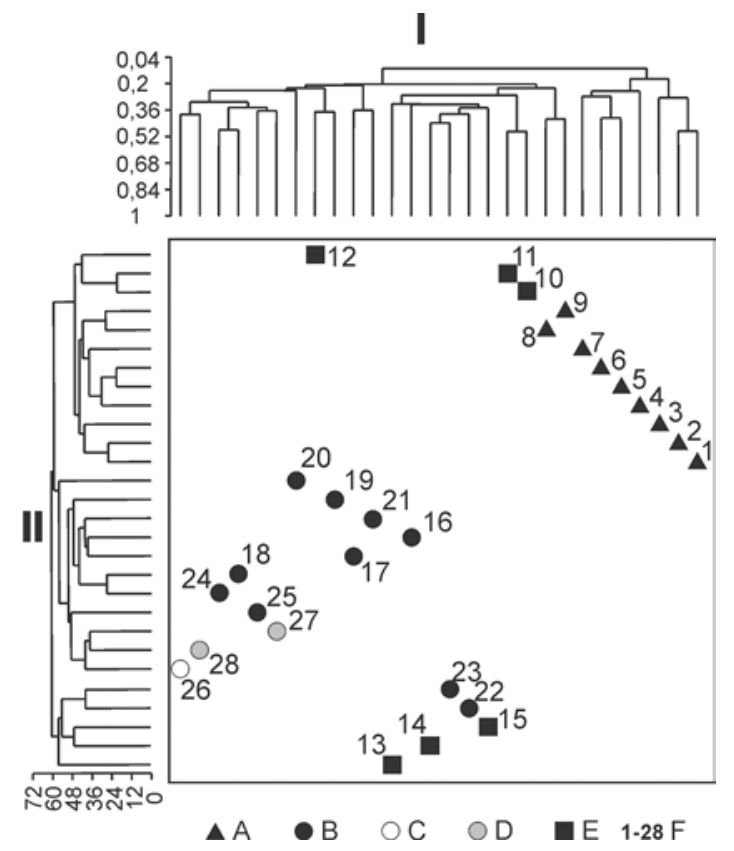

Fig. 2 Classification of spring fen relevès: I - dendrogram based on the presence/absence of species, II - dendrogram showing species coverage. A - Carici-Agrostietum caninae. B - Valeriano-Caricetum flavae. C - Caricetum davallianae. D - Eleocharitetum pauciflorae. $\mathrm{E}$ - intermediate patches. $\mathrm{F}$ - patch numbers.

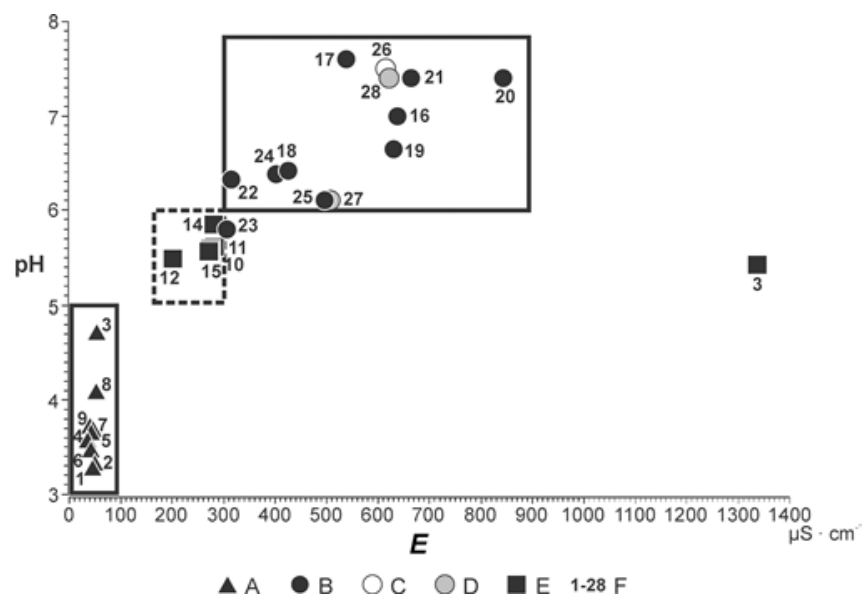

Fig. 3 Differentiation of spring fens based on soil $\mathrm{pH}$ and electrical conductivity $(E)$ of their feeding waters. A - Carici-Agrostietum caninae. B - Valeriano-Caricetum flavae. C - Caricetum davallianae. D - Eleocharitetum pauciflorae. E - intermediate patches. F - patch numbers. 
Tab. 1 (continued)

\begin{tabular}{|c|c|c|c|c|}
\hline & $\mathbf{I}$ & II & III & \\
\hline Number of relevés & $1-9$ & $10-15$ & $16-28$ & $1-28$ \\
\hline Listera ovata & - & III $^{(+-1)}$ & $\mathrm{II}^{(+-1)}$ & II \\
\hline Plagiomnium elatum & - & $\mathrm{I}^{(2)}$ & $\mathrm{IV}^{(+-4)}$ & II \\
\hline Plagiomnium rostratum & - & III $^{(1-2)}$ & III $^{(+-5)}$ & II \\
\hline Rhytidiadelphus triquetrus & - & III $^{(+-2)}$ & III $^{(+-2)}$ & II \\
\hline Tussilago farfara & - & - & III $^{(+-1)}$ & II \\
\hline Aulacomnium palustre & $I^{(+)}$ & $\mathrm{I}^{(1)}$ & $\mathrm{I}^{(1)}$ & I \\
\hline Ranunculus auricomus & $\mathrm{II}^{(+)}$ & $\mathrm{I}^{(+)}$ & $\mathrm{I}^{(+)}$ & I \\
\hline Rhinanthus serotinus & $\mathrm{I}^{(1)}$ & $\mathrm{II}^{(+-1)}$ & $I^{(+-1)}$ & I \\
\hline Salix aurita & $\mathrm{II}^{(1)}$ & $\mathrm{I}^{(1)}$ & $\mathrm{I}^{(+)}$ & I \\
\hline Salix silesiaca & $\mathrm{II}^{(+)}$ & $\mathrm{I}^{(1)}$ & $I^{(+-1)}$ & I \\
\hline Equisetum sylvaticum & $\mathrm{II}^{(+)}$ & III $^{(1-4)}$ & - & I \\
\hline Senecio subalpinus & $\mathrm{II}^{(+-1)}$ & $\mathrm{II}^{(+)}$ & - & I \\
\hline Chaerophyllum hirsutum & - & III $^{(+-1)}$ & $\mathrm{I}^{(1-2)}$ & I \\
\hline Equisetum variegatum & - & $\mathrm{II}^{(+-2)}$ & $\mathrm{II}^{(+-1)}$ & I \\
\hline Festuca ovina & III $^{(+-1)}$ & - & - & I \\
\hline Gymnadenia conopsea & - & - & $\mathrm{II}^{(+-1)}$ & I \\
\hline Eupatorium cannabinum & - & - & $\mathrm{II}^{(+-2)}$ & I \\
\hline
\end{tabular}

I - poor fens (including Carici-Agrostietum caninae); II - moderately rich fens; III - rich fens (include Valeriano-Caricetum flavae, Caricetum davallianae and Eleocharitetum pauciflorae).

$\left(\right.$ mean $=45.0$; range $\left.=36-53 \mu \mathrm{S} \mathrm{cm}^{-1}\right)$. Such extreme biotopic conditions result in the formation of a distinctive flora in poor fens, and a small degree of penetration of the association by alien species. They also result in a visible difference that enables a distinction to be made between this and neighboring associations that are already present on mineral soils. Hierarchical analysis of phytosociological relevès of Carici-Agrostietum caninae revealed the presence of a close group, that is particularly obvious in dendrogram II, based on species coverage (Fig. 2). It corroborates a small degree of differentiation of the analyzed patches and the considerable floristic distinctness of the association.

Soils colonized by Valeriano-Caricetum flavae, Caricetum davallianae and Eleocharitetum pauciflorae associations displayed higher $\mathrm{pH}$ values (Fig. 3) within the 6.1-7.6 range in $\mathrm{KCl}$ (mean 6.77) and considerable mineralization of their feeding waters, as indicated by high electric conductivity for the range 306-842 $\mu \mathrm{S} \mathrm{cm}^{-1}$ (mean 538.5). Measurements for patches classified as Caricetum davallianae and Eleocharitetum pauciflorae fell within the same ranges (Fig. 3). Quite a wide range of the described biotopic parameters, comprising both weakly acid soils through neutral to alkaline, resulted in considerable variation in the Valeriano-Caricetum flavae. Intermediate soil conditions of some patches favored the penetration of the association by species typical of other, mainly meadow, rushes and tall herb communities. The outcome was the presence of a considerable number of plants typical of wet meadows, and blurred boundaries to the majority of fens, caused by their transition into surrounding meadow or tall herb communities. Hierarchical numerical analysis of phytosociological relevès of Valeriano-Caricetum flavae revealed that they do not form such tight groups as the Carici-Agrostietum caninae association, indicating their considerable similarity to transitional patches. This is best seen in dendrogram I, which is based on the species present (Fig. 2), and where a single group contains patches classified as typical Valeriano-Caricetum flavae, as well as intermediate patches. This demonstrates the great diversification of the association. Patches classified as Caricetum davallianae and Eleocharitetum pauciflorae partly overlapped with ValerianoCaricetum flavae.

One patch classified as Valeriano-Caricetum flavae showed a slightly lower $\mathrm{pH}$ of 5.80 when measured in $\mathrm{KCl}$ (Fig. 3), yet, simultaneously, the electric conductivity of its feeding waters was close to the lower limit of the range $\left(306 \mu \mathrm{S} \mathrm{cm}^{-1}\right)$. Vegetation growing on this patch did not differ significantly from that on other patches. Together with the adjoining patch, it inclined towards intermediate fens (Fig. 2). However, the combination of characteristic species associated with this patch, and the predominance of plants typical of Valeriano-Caricetum flavae, made it possible to classify it as this association.

Fen soils having transitory vegetation features are characterized by their possession of intermediate parameters. They belong to weakly acid soils, with a mean $\mathrm{pH}$ value of 5.59 (range $=5.42-5.85)$ in $\mathrm{KCl}$ (Fig. 3), and their feeding waters are moderately abundant in mineral compounds, as indicated by their mean electric conductivity of 261.2 (range $=201-281$ $\mu \mathrm{S} \mathrm{cm}^{-1}$ ). The ranges of $\mathrm{pH}$ values typical for this fen group fall exactly between those ranges typical of the two described plant communities. Whereas the upper limit of electrical conductivity is clearly visible, the lower limit does not conform to that considered typical of Carici-Agrostietum caninae. This is important, since typical patches of poor fens are characterized by a unique homogeneity with regard to water electrical conductivity.

The narrow range given here contains those patches with species typical of both poor and rich fens in almost equal

Tab. 2 Changes to essential properties of surface horizon soils and feeding waters, proposed initially as typical of the investigated plant communities, and that allow them to be distinguished from each other.

\begin{tabular}{|c|c|c|c|c|c|c|}
\hline $\begin{array}{c}\text { Essential properties of soils and } \\
\text { waters }\end{array}$ & $\begin{array}{c}\text { Carici-Agrostietum } \\
\text { caninae }\end{array}$ & Intermediate fens & $\begin{array}{c}\text { Valeriano-Caricetum } \\
\text { flavae }\end{array}$ & $x^{2}$ & $d f$ & $\boldsymbol{P}$ \\
\hline $\mathrm{pH}$ & $3-5$ & $5-6$ & $6-8$ & 24.67 & 2 & 0.0000 \\
\hline Electrical conductivity $\left(\mu \mathrm{S} \mathrm{cm}^{-1}\right)$ & $30-60$ & $200-300$ & $300-900$ & 24.67 & 2 & 0.0000 \\
\hline $\mathrm{CaCO}_{3}$ concentration $\left(\mathrm{g} \mathrm{kg}^{-1}\right)$ & 0 & 0 & $0-700$ & - & - & - \\
\hline Mineral content (\%) & $6-33$ & $\{22-73\}$ & $34-75$ & 15.237 & 2 & 0.0005 \\
\hline Water oxygenation $\left(\mathrm{mg} \mathrm{O}_{2} \mathrm{dm}^{-3}\right)$ & $0.1-0.3$ & $\{0.15-2.5\}$ & $0.5-5$ & 14.857 & 2 & 0.0006 \\
\hline Peat decomposition & $\mathrm{H} 2-\mathrm{H} 4$ & $\{\mathrm{H} 5-\mathrm{H} 7\}$ & H6-H9 & 12.697 & 2 & 0.0018 \\
\hline
\end{tabular}

Values which do not allow distinction between individual fen groups (overlapping ranges typical of other groups) are given in curly brackets. 
measure. However, a degree of diversification was observed in this small group, indicating a slight prevalence of species characteristic of one of the associations. Hierarchical numerical analysis (Fig. 2) demonstrated that when dendrogram II was based on species abundance, these patches became segregated into two different groups containing relevès from poor and rich fens. This diversification can be correlated with variation in other soil parameters, such as mineral content, degree of peat decomposition and differences in the oxygenation of waters feeding individual patches (Fig. 4).

Moreover, one of these investigated patches differed from all the rest and was distinguished by its extremely high electric conductivity value $\left(1337 \mu \mathrm{S} \mathrm{cm}^{-1}\right)$. Such elevated values were due to exceptionally high concentrations of chlorides resulting from disturbance of the natural environment by anthropogenic factors. This particular patch is located on a slope below and at a distance of approx. $100 \mathrm{~m}$ from the Cracow to Zakopane national road. Despite these considerable changes to the natural environment, the vegetation present on the aforementioned fen did not differ much from that found on the others. Possibly, in future, the situation will change as increased salting adversely affects some of the more sensitive species, eventually causing them to vanish. Mainly facultative halophytes (inter alia: Carex nigra, C. panicea, Equisetum palustre, Juncus articulatus) will tend to survive, together with some of the meadow species [23]. Currently they constitute about $30 \%$ of vascular plants present on this spot, however in future these proportions may change.

\section{Calcium carbonate content in spring fen soils}

Carici-Agrostietum caninae association and patches bearing transitory vegetation occur on soils lacking carbonate. The presence of calcium carbonate was found only in the soils of rich fens (Fig. 5). However, even here, it was not present in all investigated patches.

The $\mathrm{CaCO}_{3}$ concentrations of analyzed rich fen soils showed great diversity. However, the results obtained were not unanimous but fell into three ranges or groups, as shown below (Fig. 5):

(i) Fens where calcium carbonate is high or very high (range $=351-653 \mathrm{~g} \mathrm{~kg}^{-1}$ ) - Valeriano-Caricetum flavae and Caricetum davallianae patches as well as one patch of Eleocharitetum pauciflorae belong here.

(ii) Fens with low concentrations of $\mathrm{CaCO}_{3}$ (range $=50-85$ $\mathrm{g} \mathrm{kg}^{-1}$ ) - Valeriano-Caricetum flavae patches belong here.

(iii) Fens lacking carbonate or containing trace amounts of $\mathrm{CaCO}_{3}$ (range $=0-0.1 \mathrm{~g} \mathrm{~kg}^{-1}$ ) - Valeriano-Caricetum flavae patches and one patch of Eleocharitetum pauciflorae belong here.

Contrary to expectations, these enormous differences in the calcium carbonate content of the soil did not significantly affect the species composition and structure of plant communities. Patches lacking carbonate, and those containing only trace amounts of $\mathrm{CaCO}_{3}$, can be distinguished by a slightly greater amount of Carex nigra. It would also seem that Eriophorum latifolium is more characteristic of habitats with lower concentrations of calcium carbonate. Conversely, Pinguicula vulgaris and Triglochin palustre prefer habitats containing large amounts of $\mathrm{CaCO}_{3}$. Differences between patches lacking carbonate and others are more obvious, in that they more closely resemble intermediate patches, as has been shown by hierarchical numerical analysis (Fig. 2).

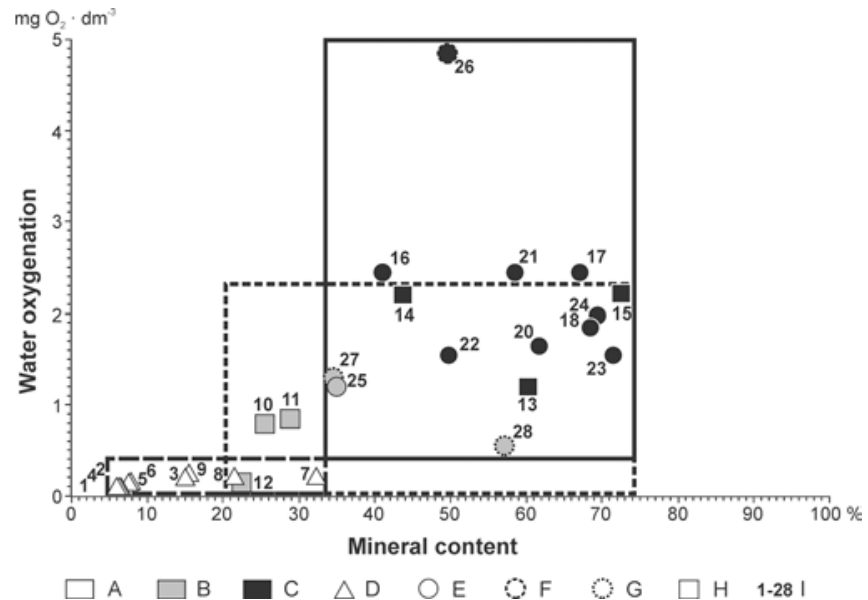

Fig. 4 Differentiation of spring fens and degree of peat decomposition (H) based on mineral content and water oxygenation. A - H2-H4. B - H5-H6. C - H7-H9. D - Carici-Agrostietum caninae. E - ValerianoCaricetum flavae. F - Caricetum davallianae. G - Eleocharitetum pauciflorae. $\mathrm{H}$ - intermediate patches. I - patch numbers.

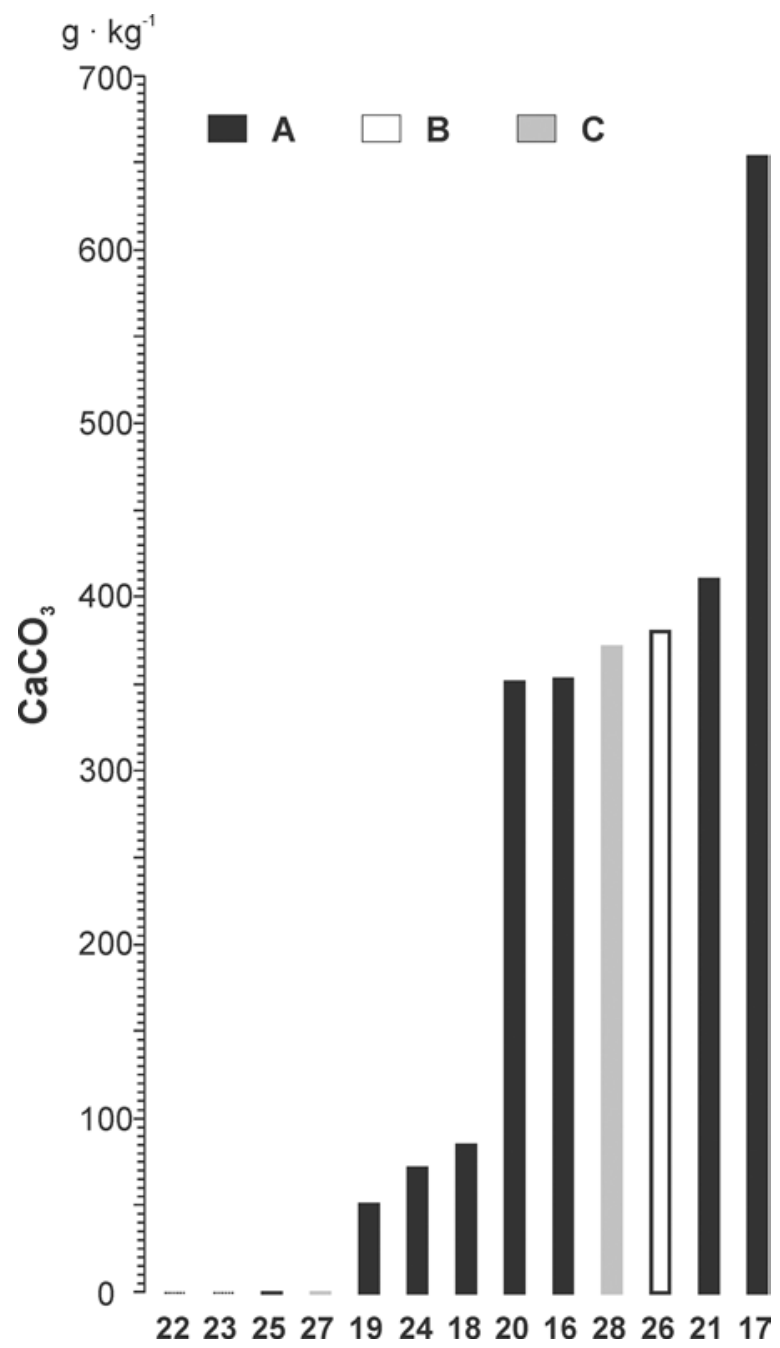

Fig. 5 Calcium carbonate concentrations in rich fen soils with Caricion davallianae vegetation. A - Valeriano-Caricetum flavae. B Caricetum davallianae. C - Eleocharitetum pauciflorae. 
Other properties of soils and their influence on the vegetation of spring fens

The described plant associations, identified on the basis of differences in their floristic composition, are the result of not only differences in the acidity and $\mathrm{CaCO}_{3}$ concentrations of the soils in which they grow, and the electrical conductance of their feeding waters, but also, the degree of peat decomposition, mineral content and oxygenation level of the feeding water. These differences are statistically significant (Tab. 2).

Carici-Agrostietum caninae association grows on peat exhibiting a low degree of decomposition $(\mathrm{H} 2-\mathrm{H} 4)$ and having a low mean mineral content of $13.1 \%$ (range $=6.0-33.3 \%$ ). Its feeding waters are extremely poorly oxygenated, having a mean value of 0.17 (range $=0.10-0.26 \mathrm{mg} \mathrm{O}_{2} \mathrm{dm}^{-3}$; Fig. 4).

Valeriano-Caricetum flavae, Caricetun davallianae and Eleocharitetum pauciflorae associations grow on peat exhibiting a high degree of decomposition (H6-H9) and having a higher mean mineral content of 56.77 (range $=34.6-74.1 \%$ ). The feeding waters show great diversity in terms of their oxygenation levels, which vary widely (mean $=1.99$; range $=0.55-4.85 \mathrm{mg}$ $\mathrm{O}_{2} \mathrm{dm}^{-3}$; Fig. 4). Despite these large differences, in the degree of water oxygenation, this factor did not have any significant effect on plant species composition (compare Fig. 2, Fig. 4).

Peat exhibiting a low or medium degree of decomposition ( $\mathrm{H} 5-\mathrm{H} 7)$ occurs in the substratum of fens covered by transitional type of vegetation, the degree of decomposition depending on its floristic composition. Mineral content fluctuates widely from 22.3 to $72.5 \%$ (mean $=42.12$; Fig. 4 ), and enters the ranges typical for both Carici-Agrostietum caninae and Valeriano-Caricetum flavae. The values of fen-feeding water oxygenation are similar, and fluctuate from 0.15 to 2.21 $\mathrm{mg} \mathrm{O}_{2} \mathrm{dm}^{-3}$ (mean =1.23). It would seem that the boundaries between the ranges for mineral content and water oxygenation typical for both investigated associations, are crucial for their vegetation structure. Fens with vegetation of intermediate characteristics are closer to Carici-Agrostietum caninae, or to Valeriano-Caricetum flavae, depending on the values of the described parameters (compare Fig. 2, Fig. 4).

\section{Discussion}

Fens bearing typically formed Carici-Agrostietum caninae and Valeriano-Caricetum flavae associations differ fundamentally in relation to the properties of their soils and feeding waters. Mineral content, $\mathrm{pH}, \mathrm{CaCO}_{3}$ concentration and the degree of peat decomposition, as well as electrical conductivity and the oxygenation of fen-feeding waters do not tally. Parameter ranges typical for each of these two associations can easily be determined as an initial step in their characterization (Tab. 2). Carici-Agrostietum caninae is a uniform association adapted to extreme biotopic conditions. It is characterized by its very narrow range of soils and feeding-water parameter values. Valeriano-Caricetum flavae is a most diverse association. The considerable diversity of its species composition and plant structure reflects a very wide range of basic soil and feeding water parameters. The character of its vegetation depends mostly on fen soil $\mathrm{pH}$ and the degree of mineralization of its feeding water. It is only these parameters that seemingly distinguish patches that bear vegetation of intermediate character. They cannot be identified easily based on the degree of peat decomposition, mineral content and level of water oxygenation. These parameters are different for Carici-Agrostietum caninae and
Valeriano-Caricetum flavae, whereas intermediate patches are able to grow in the typical ranges characteristic of both investigated associations. Moreover, the vegetation of these patches is able to diversify to such an extent that the latter resembles one of the two investigated associations.

The results obtained in this study generally agree with those obtained for other studies of spring fens in the Carpathians $[24,25]$, although we identified fewer plant communities. The chemical properties of both soil and water in Carici-Agrostietum caninae correspond with those typical of Carici echinataeSphagnetum sphagnetosum fallacies, a community identified in the Czech Republic and Slovakia [11,24]. The parameters exhibited by Valeriano-Caricetum flavae are also similar. Patches of intermediate $\mathrm{pH}$ represent Carici echinatae-Sphagnetum sphagnetosum flexuosi, but their electrical conductivity is typical of Valeriano-Caricetum flavae [24].

The concentration of calcium carbonate in some spring fens was found to be very high and considerably exceeded those concentrations reported from spring fens for other areas of the Western Carpathians [25]. These differences were due to two factors. Firstly, in our study, the concentration of calcium carbonate was determined for soil, whereas other authors based their results on the analysis of water. Secondly, our study included fens located both on flysch and on calcareous substrate. However, earlier studies were restricted to fens of the flysch region.

Plant species characteristic of Sphagno warnstorfi-Eriophoretum latifolii and Caricion lasiocarpae alliances (Sphagnum teres, S. warnstorfii and Tomentypnum nitens) represented only a small proportion of plants from both the Valeriano-Caricetum flavae and fens with the intermediate type of vegetation. Sphagno warnstorfi-Eriophoretum latifolii occurs in the investigated area [17], but was not present in those fens selected for this study. None of the conductivity values obtained fell within the range characteristic of this plant association [24].

Some characteristics discovered in our study have previously been reported from the Western Carpathians [24], e.g., the wide tolerance of Eleocharitetum pauciflorae to the $\mathrm{CaCO}_{3}$ content of soil, its floristic similarity to Valeriano-Caricetum flavae and the similar ranges of basic soil parameters. We also demonstrated that a high proportion of spring species present in the moss layer is typical of fens located on slopes with running water.

\section{Acknowledgments}

This research was supported by grant No. 2 P04G 07329 of National Committee for Scientific Research (KBN).

\section{Authors' contributions}

The following declarations about authors' contributions to the research have been made: collecting data (vegetation sampling), data analyzes and interpretation, writing the manuscript, table and figures arrangement: AK; research designing, collecting data (soil and water sampling, chemical analyzes), writing the manuscript: PN.

\section{References}

1. Nicia P, Miechówka A. General characteristics of eutrophic fen soil. Pol J Soil Sci. 2004;37(1):39-47. 
2. Nicia P, Bejger R, Mazurek R, Zadrożny P. Characteristics of low sedge oligotrophic fen soils in the Podhale Region and the Beskid Wsypowy Mts. In: Brandyk T, Szajdak L, Szałtyłowicz J, editors. Chemical and physical properties of organic soils. Warsaw: WULS-SGGW; 2006. p. 187-194.

3. Matuszkiewicz W. Przewodnik do oznaczania zbiorowisk roślinnych Polski. Warsaw: Polish Scientific Publishers PWN; 2007.

4. Mazurek R, Nicia P. Micromorphological properties of low sedge mountain fen soils. Pol J Env Stud. 2006;5(5D):80.

5. Kornaś J, Medwecka-Kornaś A. Plant communities of the Gorce Mts. (Polish Western Carpathians). I. Natural and seminatural non-forest communities. Fragm Flor Geobot. 1967;13(2):167-316.

6. Pawłowski B. Szata roślinna gór polskich. In: Szafer W, Zarzycki K, editors. Szata roślinna Polski. Warsaw: Polish Scientific Publishers PWN; 1972. p. 189-252. (vol 2).

7. Sapek A, Sapek B. Metody analizy chemicznej gleb organicznych. Falenty: Institute for Land Reclamation and Grassland Forming IMUZ; 1997.

8. Ilnicki P. Torfowiska i torf. Poznań: A. Cieszkowski Agricultural University; 2002.

9. Dojlido J. Fizyczno-chemiczne badanie wody i ścieków. Warsaw: Arkady; 1999.

10. Ratyńska H, Wojterska M, Brzeg A. Multimedialna encyklopedia zbiorowisk roślinnych Polski. Warsaw: NFOSiGW; 2010. (vol CD 1-2).

11. Chytrý M, editor. Vegetation of the Czech Republic 3. Aquatic and wetland vegetation. Prague: Academia; 2011.

12. Pawłowski B, Pawłowska S, Zarzycki K. Zespoły roślinne kośnych łąk północnej części Tatr i Podtatrza. Fragm Flor Geobot. 1960;6(2):95-222.

13. Grodzińska K. Meadow and field associations of the Gubałówka elevation (Polish Western Carpathians). Fragm Flor Geobot. 1961;7(2):357-418.

14. Grodzińska K. Flora and vegetation of the Nowotarskie and Spiskie Klippen (Pieniny Klippen-belt). Fragm Flor Geobot. 1975;21(2):149-246.

15. Stuchlikowa B. Meadow associations of the Polica range (Polish Western Carpathians). Fragm Flor Geobot. 1967;13(3):357-402.
16. Medwecka-Kornaś A, Kornaś J, Pawłowski B, Zarzycki K. Przegląd zbiorowisk roślinnych lądowych i słodkowodnych. In: Szafer W, Zarzycki K, editors. Szata roślinna Polski. Warsaw: Polish Scientific Publishers PWN; 1972. p. 237-502. (vol 1).

17. Hájek M. The Valeriano simplicifoliae-Caricetum flavae association in the Podhale region (West Carpathians, Poland): notes on syntaxonomical and successional relationships. Fragm Flor Geobot. 1999;44:389-400.

18. Mirek Z, Piękoś-Mirkowa $\mathrm{H}$, Zając A, Zając M. Flowering plants and pteridophytes of Poland a checklist. Cracow: W. Szafer Institute of Botany, Polish Academy of Sciences; 2002. (Biodiversity of Poland; vol 1).

19. Ochyra R, Żarnowiec J, Bednarek-Ochyra H. Census of Polish mosses. Cracow: W. Szafer Institute of Botany, Polish Academy of Sciences; 2003. (Biodiversity of Poland; vol 3).

20. Sokal RR, Rohlf FJ. Biometry. The principles and practice of statistics in biological research. New York NY: Freeman; 1981.

21. Gauch HG. Multivariate analysis in community ecology. Cambridge: Cambridge University Press; 1986.

22. Jongman RH, ter Braak CJF, van Tongeren ORF. Data analysis in community and landscape ecology. Wageningen: Pudoc; 1995.

23. Zarzycki K, Trzcińska-Tacik H, Różański W, Szeląg Z, Wołek J, Korzeniak U. Ecological indicator values of vascular plants of Poland. Cracow: W. Szafer Institute of Botany, Polish Academy of Sciences; 2002. (Biodiversity of Poland; vol 2).

24. Hájek M, Hájková P. Vegetation composition, main gradient and subatlantic elements in spring fens of the north-western Carpathian borders. Thaiszia. 2002;12:1-24.

25. Hájek M, Hekera P, Hájková P. Spring fen vegetation and water chemistry in the Western Carpathian flysch zone. Folia Geobot. 2002;37:205-224. http://dx.doi.org/10.1007/BF02804232

26. Kondracki J. Geografia regionalna Polski. 2nd ed. Warsaw: Polish Scientific Publishers PWN; 2001. 